\title{
Socio-Economic Characteristics of Palm Oil Marketers in Nkanu East L.G.A of Enugu State, Nigeria
}

\author{
Nnaji J.O., Abdulshakur M.M., A. Al-Mustapha., A. Haruna., Fatima Z.I., and Eze P.U.
}

National Agricultural Extension and Research Liaison Services, Ahmadu Bello University, Zaria Nigeria

*Corresponding Author

Nnaji JO

\section{Article History}

Received: 30.11 .2019

Accepted: 08.12.2019

Published: 22.12.2019

\begin{abstract}
This study was conducted to determine socio-economic characteristic and identify constraints of palm oil marketers in Nkanu East Local Government Area of Enugu State, Nigeria. Both Secondary and Primary Data were used for data collection. Percentage and frequency distribution were used to determine the socio-economic characteristic of palm oil marketers and the identification of the constraints facing the level of palm oil marketers, the result showed that $60.83 \%$ of the respondents were females, while $37.17 \%$ were males. The Age bracket of $31-40$ constituted the majority (37.50\%) of palm oil marketers in the study area. The result also indicates that married people were more involved in the palm oil marketing which accounted for $51.7 \%$ in the study area. $40.00 \%$ of the respondents had primary education, while the least $13.33 \%$ had tertiary education. The major sources of income of the respondents were trading which accounted for $37.50 \%$; this shows that palm oil business is a profitable enterprise and it worth investing. It was observed that palm oil marketer's years of experience of respondents were within the bracket of $5-9$ years which accounted for $35.00 \%$, while the least $15 \%$ and above were $11.67 \%$. The major constraints of palm oil marketers in the study area were: lack of capital incentives $(29.17 \%)$, the use of unimproved varieties $(20.83 \%)$, lack of essential infrastructure $(19.17 \%)$, high purchase price of fruits $(12.50 \%)$, Charges on taxes $(10.00 \%)$, Seasonal of product $(8.33 \%)$. The study recommends that capital should be made available to the palm oil marketers for them to sell and transport their palm oil to the urban areas where they will make more income as a trader. Extension agent should provide informal education on marketing strategies and marketing structure which will improve their palm oil business in Nkanu East L.G.A of Enugu State, Nigeria.
\end{abstract}

Keywords: Socio-economic, Constraints, Palm oil, Nkanu East L.G.A.

\section{INTRODUCTION}

Palm oil has been a significant ingredient in the diet of many Nigerians. Palm oil is the world's major source of edible oil, accounting for 38.5 million tonnes or $25 \%$ of the global edible oil and fat production [17]. Palm oil is a product extracted from the fleshy mesocarp of the palm fruit (Elaeis guineensis). The global demand for palm oil is growing thus, the crop cultivation serves as a means of livelihood for many rural families, and indeed it is in the farming culture of millions of people in the country. Hence, oil palm is often referred to as a crop of multiple values, which underlines its economic importance [1]. The demand for domestic and industrial application of palm oil has continuously to increase [11]. It is estimated that for every Nigerian household of five, about two liters of palm oil are consumed weekly for cooking [3]

Oil palm as an economic and important tree is normally believed to be of West African origin. The African oil palm (Elaeis guinensis) is a native to West and Southwest Africa, occurring between Angola and Gambia [15]. It is recognized to produce more oil per hectare than any other oil crop. In most West African countries, including Nigeria, the palm trees grow naturally in the rain forest zones where annual rainfall is between $125-660 \mathrm{~cm}$ and annual temperature ranges from $20-34^{\circ} \mathrm{C}$. Many plantations of oil palm produce are obtained from growing wild [15]. Palm oil is world's second major vegetable oil, after soybean with world annual production of fresh fruit bunches approaching 100 million metric tons per year [13]. This is in line with [12], who stated that palm oil is currently the second largest traded edible oil and accounts for about one quarter of the world's fats and oil supply [12] also noted that palm oil is not only used domestically (as edible oil) but is applied to a wide variety of uses including the manufacture of candles, soaps, margarine and several others. This accounts for the high demand on the product and the consequent need to increase production.

Copyright @ 2019: This is an open-access article distributed under the terms of the Creative Commons Attribution license which permits unrestricted use, distribution, and reproduction in any medium for non commercial use (NonCommercial, or CC-BY-NC) provided the original author and source are credited. 
The main palm oil producing states in Nigeria include Cross River, Abia, Akwa Ibom, Imo, Rivers, Anambra, Enugu, Ogun, Delta, Edo, Oyo and Ekiti [16]. Palm oil Production in Nigeria has declined compared to what was obtainable in the historical. Nigeria which was the world's leading producer of palm oil in 1950s and early 1960s is now the third world's largest producer of palm oil, producing only 3.6\% of the world's total palm oil in 2002 [4]. The cause of this decrease is traceable to the civil war of 1967 to 1970 as well as the general neglect of Agriculture upon the discovery of petroleum. Efforts made towards raising production again have not been as successful as expected [14] reported that in Nigeria, $80 \%$ of production comes from dispersed small holders who harvest semi-wild plants and use manual processing technique. The estimate for oil palm plantation in Nigeria ranges from 169,000 to 360,000 hectares of plantations [2]. In addition to the agro climatic and structural factors (size and scale of production and processing sectors), there are other constraints like little use of modern inputs and extension service, low provisions of market information, standards and quality control [7]. At the same time the rapid devaluation of the naira combined with high transportation cost from parts to internal market put imported oil in a competitively disadvantaged position [7]. Thus, Nigeria's first goal is to meet the domestic demand and then if possible, seek to become competitive in export markets. Nigeria palm oil production is potentially competitive in the domestic market; oil palm would enhance the overall economic development through the income and employment effects in the rural and urban economies [7, 9]. Stated that Nigeria has huge potential to increase her production of palm oil and kernel primarily through application of improved processing techniques [6], also noted, that improved technologies that meet both growth and sustainability goals can be effectively used by oil palm processors, however, most technologies are design for developed rather than developing countries [9], also reported that until the private sector of the economy involves in mass production of palm oil, Nigeria would continue to remain a net importer of the zero produce despite the existence of Nigerian Institute for Oil Palm Research (NIFOR) founded in 1939 by the colonial masters to carryout research on palm oil. Palm oil production is still faced with a lot of problems including; inadequate finance, shortage of labour, scarcity of water and firewood and lack of effective processing techniques in palm oil production [9].

In order to fill in the above stated gaps, this work tends to determine socio-economic characteristic and identify constraints of palm oil marketers in the study area. This is because there is no known research been done in the study area on the stated problems. For the purpose of the problems, this work intends to provide answer to some pertinent questions stated below: What are the famer's socio-economic characteristics? And what are the constraints facing the level of palm oil marketers in the study area?

\section{OBJECTIVES OF THE STUDY}

- Describe the socio-economic characteristics of the palm oil producers in study area.

- Identify the constraints facing the level of palm oil production in the study area.

\section{METHODOLOGY}

\section{Study Area}

The study was conducted in Nkanu East Local Government Area of Enugu State. Nkanu East is located in a tropical rain forest zone with a derived savannah. The Local Government Area has a tropical savanna climate and its climate is humid and this humidity is at its highest between March and November [19]. The study area is bounded in the North by Ishielu Local Government Area of Ebonyi State and Isi - Uzo Local Government Area of Enugu State, in the south by Ohaozara Local Government Area, of Ebonyi State, in the East by Enugu East Local Government Area of Enugu State and in the west by Aninri Local Government Area, Enugu State. Its headquarters is in the town of Amagunze. It has a population of 148,774 [5], and a landmass of $795 \mathrm{~km}^{2}$. It is located between Latitude $6{ }^{0} 0^{1}$ and $6.33^{\circ}$ north of the Equator and Longitude $7039^{1}$ and $7.65^{\circ}$ of the GreenWich Meridian. During the raining season, Nkanu East receives an annual rainfall of $1,750-2000 \mathrm{~mm}$ that lasts from April to October, with annual temperature of about $750 \mathrm{f}$ and $800 \mathrm{f}$ which combines to make the climate genial and equable [19]. 


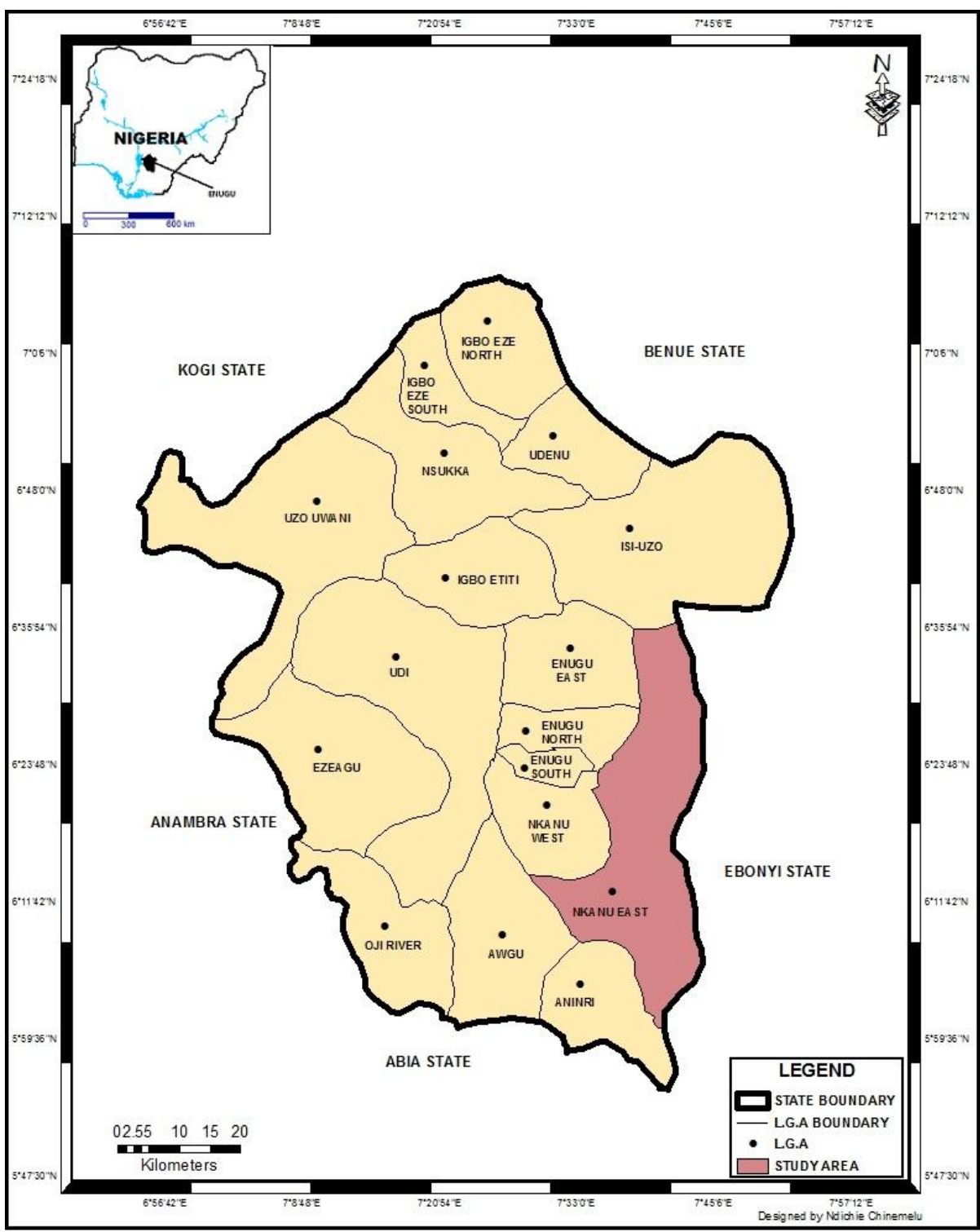

Source: Egbo, (2014). (Map of Enugu State Showing the Study Area level)

Nkanu East, as one of the seventeen Local Government Area in Enugu State is an Igbo dominated tribe, and one of the Local Government in Enugu East Senatorial Zone that falls within the savannah region of the former Eastern Nigeria, usually characterized by tall trees and grasses. In Nkanu East, there are trees like palm trees, oil bean, bread fruit, plantain, paw-paw, orange etc. The Local Government is Located at the town of Amagunze. Nkanu East L.G.A is mainly agrarians, some economic activities engaged by the people are, hunting, vulcanizing, road side mechanic, petty trading, barbing salon, palm oil marketing and palm wine marketing.

\section{DATA COLLECTION}

Data for this research was collected from to source namely; primary and secondary source. Multistage sampling procedure was used to select communities, Villages and Marketers. The first stage involved a purposive selection of six (6) communities out of the thirty-three communities that made up the Local Government Area, in the second stage, four (4) Villages was randomly selected from each of the selected communities to make a total of 24 villages, in the third stage, five (5) palm oil marketers was randomly selected from each of the selected villages to get a total of one hundred and twenty (120) palm oil marketers which is the sample size for the study. Data were collected using a structured questionnaire; the data collected was analyzed based on the specific objectives of the study. Objective i and ii (socio-economic characteristic of palm oil marketers and identification of the constraints facing palm oil marketers in the study area respectively) was captured using percentage and frequency distribution. 


\section{RESULT AND DISCUSSION}

\section{Socio-Economic Characteristics of Palm Oil Marketers}

Findings on socio-economics characteristics of the palm oil marketers (Table 1) reveal that, $39.17 \%$ of the respondents are male, while $60.83 \%$ are female. This indicates that majority of palm oil marketers in Nkanu East Local Government Area were females. According to [8] reported that there has been a great disparity between male and female farmers. Findings revealed that majority (37.50\%) of the respondents were between the age of 31-40 years and least $5.00 \%$ falls within age above 50 . According to [8], stated that age has strong relationship on the output of palm oil production. Table 1 reveals that majority $(51.7 \%)$ of the respondents were married, while only $10 \%$ single. From the data collected, it was observed that majority of palm oil farmers in Nkanu East Local Government Area were married people. This study is in line with the findings of [20] who reported that married people are often associated with children who could be used in completing certain agricultural activities in the farm; especially where they are of labour age. Result from the finding reveals that $15.83 \%$ of the respondents had non-formal education while $40.00 \%$ attended primary school. These indicate that majority of palm oil marketers that engaged in palm oil marketing in Nkanu-East Local Government Area attended primary schools. This finding is contrary to the findings of [10] that most (76\%) of the marketers did not have degree certificate. Findings from table 1 show that $15.00 \%$ of the respondents are salary earners, while the majority $(37.50 \%)$ of the respondents is traders. This indicated that farmers in the study area derived their source of income from trading. The result reveals that majority (35.00\%) had between $5-9$ years of experience while $11.67 \%$ had between 50 and above years of experiences. This implies that the respondents had considerable experience that may enhance their level of output.

\begin{tabular}{|ll|}
\hline \multicolumn{2}{|l|}{ Table-l: Distribution of respondents on socio-economic characteristics } \\
\hline Variables & $\%$ \\
\hline Sex & \\
Male & 39.17 \\
Female & 60.83 \\
Marital Status & \\
Single & 22.4 \\
Married & 51.7 \\
Widow & 16.7 \\
Widower & 9.2 \\
Age (in years) & \\
Below 20 & 8.33 \\
21 - 30 & 35.83 \\
31 - 40 & 37.50 \\
41 - 50 & 12.50 \\
Above 50 & 5.83 \\
Educational Level & \\
No formal education & 15.83 \\
Primary school & 40.00 \\
Secondary school & 30.83 \\
Tertiary institution & 13.33 \\
Major source of income & \\
None & 25.00 \\
Salary & 15.00 \\
Trading & 37.50 \\
Remittance & 18.33 \\
Others & 4.17 \\
Years of experience & \\
less than 5 years & 30.00 \\
5-9 years & 35.00 \\
10-14 years & 23.33 \\
15 and above & 11.67 \\
\hline & \\
& \\
\hline
\end{tabular}

\section{Distribution of Respondents According to constraints}

From table 2, the study revealed that majority $(29.17 \%)$ of the respondents complained of Lack of capital incentives as the major problem they faced in their business. $20.83 \%$ of the respondents complained of use of unimproved varieties for the processing of the palm fruits. About $19.17 \%$ of the respondents complained of lack of essential infrastructure, this might be the reason for rural to urban areas, also $12.50 \%$ complained about high purchase price of fruits, $8.33 \%$ complained about seasonal of product as a constraint they faced in palm oil business and $10.00 \%$ complained about charges on taxes encountered every day in the market.

\begin{tabular}{|lll|}
\hline \multicolumn{3}{|l|}{ Table-2: Distribution of Respondents According to constraints } \\
\hline Constraints & Frequency & Percentages \\
\hline Use of unimproved varieties & 25 & 20.834 \\
Lack of es sential infrastructure & 23 & 19.17 \\
Lack of capital incentive & 35 & 29.17 \\
High purchase of palm fruits & 15 & 12.50 \\
Seas onal of product & 10 & 8.33 \\
Charges on taxes & 12 & 10.00 \\
\hline Total & 120 & 100 \\
\hline Source: Field Survey, 2016 & & \\
\hline
\end{tabular}




\section{CONCLUSION AND RECOMMENDATION}

In line with the findings of the study, it is therefore, concluded that palm oil business in the study area is efficient and profitable as marketers within the study areas ventures into it as they source of income. The farmers had low level of education, while their major source of income is trading. It was also observed that palm tree used for the production of palm fruits are unimproved varieties and lack of capital incentive to boost their business came with the highest percentage from the result of constraints faced in their line of business. Based on the findings in the study area, the following are recommended; that capital should be made available to the palm oil marketers for them to sell and transport their palm oil to the urban areas where they will make more income as a trader and more efforts should be intensified on the part of extension agents to provide informal education on marketing strategies and marketing structure which will improve their palm oil business in Nkanu East L.G.A of Enugu State, Nigeria.

\section{REFERENCES}

1. Akangbe, J.A., Adesiji, G.B., Fakayode, S.B., \& Aderibigbe, Y.O. (2011). Towards palm oil self - sufficient in Nigeria, constraints and training needs. Nexus of palm oil extractors J.Hum. Ecol, 33(2):139 - 145

2. Carrere, R. (2010). Oil palm in Africa: Past, present and future scenarios. WRM series on tree plantations, $15,111$.

3. Ekinne, D.I., \& Onu, M.E. (2008). "Economics of small - scale palm oil processing in Ikwere and Etche Local Government Areas of Rivers State, Nigeria. Journal of Agriculture and social research, 8(2): $1-9$.

4. Poku, K. (2002). Small-scale palm oil processing in Africa (Vol. 148). Food \& Agriculture Org.

5. NPC. (2006). National Population Commission, report of National census. "Nkanu East L.G.A chapter", Abuja report.

6. Nwawwe, C. N., \& Edokpayi, A. A. (2005). Determinations of adoption of improved oil palm production technologies in Delta State, Nigeria. J. Agric. For. Soc. Sci, 3(2), 10-16.

7. Olagunju, F.I. (2008). Economics of palm oil processing in southeastern Nigeria. International journal of agricultural economics and rural development, 1(2):69 - 77.

8. Okelola, O. E., Olabode, A.D., Anozie, R.O., \& Ariyo, O.C. (2014). Economics Analysis of Palm Oil Marketing in Imo State, Nigeria. Journal of Agricultural Research (TAJAR), 2(2): 32-36.

9. Omueti, U. (2003). "The oil palm in Nigeria. Paper presented to the regional group meeting in palm oil sector development, organized by UNIDO, $16^{\text {th }}-19^{\text {th }}$ December, 2003. Akosonbo, Ghana.

10. Umoinyang, M.E. (2014). Economics of fish marketing in Akwa Ibom State, Nigeria. Masters Dissertation, Department of Agricultural Economics, University of Nsukka, Enugu State

11. Omereji, G.O. (2005). The Oil Palm Industry in Nigeria: cultivation, Processing and Trade. Mindex publishers, Benin City, 131156

12. Ibekwe, U.C. (2008). Role of Women in Oil Palm Fruit Processing and Marketing in Imo State. Federal University of Technology, Owerri, Nigeria. Medwell journals, 4(2): 101-109.

13. Ada-Okungbowa, C.I., Ogborodi, O., Omofunwa, E.I. (2013). Profitability of palm oil marketing in Ethiope East L.G.A. of Delta state, Nigeria. J. Applied Sci. Agricu, 8(4): 342-345.

14. Ibitoye, S.J. (2014). Economic Analysis Of Palm Oil Marketing In Dekina Local Government Area Of Kogi State, Nigeria. Asian J. Soc. Sci., Arts Hum, 2(1) 1-19.

15. Mathew, O. (2009). Edible Oil Today Section of Manufacturer Association of Nigeria; Nigeria Palm Oil Today and Future Outlook. Paper presented at Nigerian Institute for Oil Palm Research Workshop, January 2009.

16. Iwuji, J. (2014). Structure, Conduct and Performance of palm oil marketing in Abia and Kaduna states, Nigeria. A M.Sc thesis submitted to the school of postgraduate studies, ahmadu bello university, zaria, agricultural economics.

17. MPOC. (2007). World oil production. http://www.mpoc.org.my;assessed June 30th, 2012.

18. Omoti. U. (2001). "The future of the oil palm industry in Africa and strategies for development. The Nigeria situation ". Paper prepared for the Africa development bank workshop on the future of oil palm industry in Africa and strategies for development, Cote d'ivoire.

19. Egbo, O.C. (2014). Early human settlement patterns in Nkanu East Local Government Area, Enugu State. A M.A thesis submitted to the department of archaeology and tourism, faculty of arts, University of Nigeria, Nsukka

20. Iheke, R.O. (2006). Gender and resource use efficiency in rice production system in Abia State, Nigeria. An unpublished M.S.c Thesis. Michael Okpara University of Agriculture, Umudike. 